\title{
A note on analysis of chromosome constitution in tissues, quality of semen and DNA microsatelite loci in bull with $60, \mathrm{XY} / 61, \mathrm{XYY}$ karyotype
}

\author{
K. Jaszczak, R. Parada, B. Wardęcka and C. Niemczewski \\ Department of Molecular Cytogenetics, \\ Institute of Genetics and Animal Breeding, Polish Academy of Sciences \\ Jastrzębiec, 05-552 Wólka Kosowska, Poland
}

(Received 30 June 2003; accepted 15 July 2003)

\begin{abstract}
When analysing the karyotype of young Holstein-Friesian bull, two cell lines were observed - with chromosomes 60,XY and 61,XYY, in a culture of blood lymphocytes. The mean per cent of cells with karyotype $60, X Y$ amounted to 72 , while with karyotype $61, X Y Y-28$. The subsequent cytogenetical tests, conducted when the bull reached 16 months of age, also demonstrated the occurrence of two cell lines in cultures of skin, kidney, spleen and lung fibroblasts. The ratio of cells with karyotype 60,XY:61,XYY was as follows: 72:28 in skin, 68:32 in kidney, 62:32 in spleen and 61:39 in lung. Moreover, the examinations of meiotic chromosomes demonstrated the presence of bivalents $\mathrm{XY}$ and trivalents XYY. The bull showed a normal growth rate and live body weight and normally developed sexual organs. The evaluation of the bull's semen, conducted at the age of 14 months, showed that it meets the standards accepted for sires maintained in AI stations.

An analysis of the polymorphism of 11 microsatellite DNA sequences was performed for the bull examined and his parents, using a commercial StockMarks for Cattle Bovine II v. 2 PCR Typing Kit. An additional third allele was identified at locus ETH3, what indicates the presence of cell chimerism in the 60,XY/61,XYY bull examined.
\end{abstract}

KEY WORDS: bull, 60,XY/61,XYY karyotype, semen characteristics, microsatelities

\section{INTRODUCTION}

Numerical chromosome aberrations involving autosomes are rarely observed in mammals. Those animals with trisomes, that have been born, are usually severely 
deformed (Gustavsson, 1984). Aneuploidies of sex chromosomes are frequently seen in animals surviving birth because these aberrations are more easily tolerated by embryo or the newborn (Breeuwsma, 1968; Fretz, 1976; Höhn et al., 1980). The pure XYY condition, which is frequently associated with reduced fertility, has been observed in mice (Evans et al., 1978) and in human beings (Skakkebaek et al., 1973). In cattle the pure 61,XYY karyotype has as yet never been described, but three cases of mosaic $60, \mathrm{XY} / 61, \mathrm{XYY}$ bulls have been reported (Miyake at al., 1984).

An earlier report presented the case of a Holstein-Friesian bull with two lymphocyte lines - 60,XY and 61,XYY (Jaszczak et al., 2002). The present report describes the subsequent cytogenetic analysis of other tissues and the semen quality. A DNA microsatelite loci analysis was also carried out in order to explain the origin of this chromosome abnormality.

\section{MATERIAL AND METHODS}

Chromosome preparations were made from cell cultures of blood lymphocytes and fibroblasts of skin, kidney, spleen and lung tissue. Biopsies from solid bull tissues were taken at the age of 16 months, during slaughter. Primary cell cultures were established after treating with colagenase in RPMI 1640 medium, supplemented with 20\% fetal calf serum and harvested 6-10 days later, after one or two subcultures. Metaphase spreads from phaseolin stimulated blood lymphocytes were prepared according to standard procedures. Chromosome slides were stained by the routine Giemsa method and CBG banding (Sumner, 1972). The proportion of $60, \mathrm{XY}$ to $61, \mathrm{XYY}$ cells was recorded on at last 100 metaphase plates for each tissue. Moreover, preparations of meiotic chromosomes were made from testicular biopsies, using the air drying method (Evans et al., 1964).

The semen quality of the bull was evaluated once, at the age of 14 months. The following semen parameters were analyzed: volume of ejaculate $(\mathrm{ml})$, spermatozoa motility (\%), sperm concentration (in $\mathrm{ml}$ ) and spermatozoa morphology (\% of major and minor defects).

DNA samples for microsatelite analysis were obtained from the spleen and kidney of the XY/XYY bull, from the blood of his dam and the semen of his sire. DNA was extracted using the NucleoSpin Tissue Kit (Macherey- Nagel).

The following microsatellite loci have been chosen for analyses: TGLA227, BM2113, TGLA53, ETH10, SPS115, TGLA126, TGLA122, INRA23, ETH3, ETH225 and BM1824. These microsatellite markers are commercially available in the StockMarks for Cattle Parentage Verification Kit, Bovine II ver.2 (Perkin Elmer). DNA samples were amplified according to manufacturer protocol (Perkin 
Elmer). The PCR products were separated in 4\% polyacrylamide gel (6M urea) on an ABI PRISM 377 DNA sequencer (applied Biosystems, Perkin Elmer), using a geneScan-350 internal size standard, labelled with a TAMRA dye. Fragment sizes were determined automatically using the GeneScan v. 2.1 software (Perkin Elmer).

\section{RESULTS AND DISCUSSION}

Results of the cytogenetic analysis of several tissues obtained from a bull with two lymphocyte lines are presented in Table 1. In fibroblast cultures from skin, kidney, spleen and lung two cell populations were found - with XY and XYY sex chromosomes (Figure 1). The proportion between 60,XY and 61,XYY cells in the solid tissues analysed was similar to that observed in the blood lymphocyte culture (70:30).

TABLE 1

Per cent of cells with kayotype 60,XY and 61,XYY in tissues of the bull examined

\begin{tabular}{lcc}
\hline & \multicolumn{2}{c}{ Per cent of cells } \\
\cline { 2 - 3 } & $60, \mathrm{XY}$ & $61, \mathrm{XYY}$ \\
\hline Lymphocyte & 72 & 28 \\
Skin & 72 & 28 \\
Kidney & 68 & 32 \\
Spleen & 62 & 38 \\
Lung & 61 & 39 \\
\hline
\end{tabular}

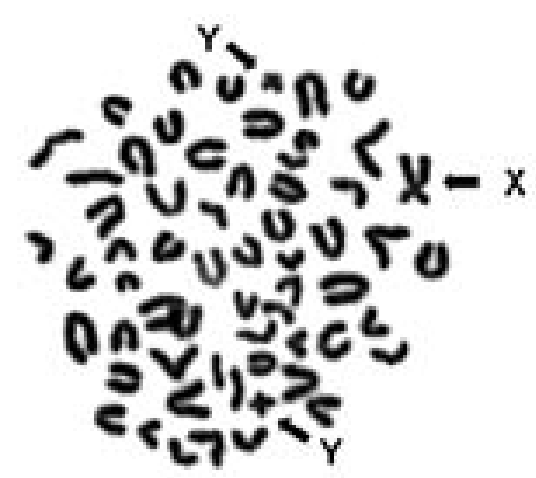

Figure 1. Metaphase spread from culture of 60,XY/61,XYY bull skin fibroblasts 
Characteristics of ejaculate produced by $60, \mathrm{XY} / 61, \mathrm{XYY}$ bull

\begin{tabular}{lc}
\hline Parameters of semen & Ejaculate \\
\hline Volume, $\mathrm{ml}$ & 3.4 \\
Colour & white-cream \\
Sperm concentration $/ \mathrm{ml}, \mathrm{x} 10^{6}$ & 1100 \\
Reaction, $\mathrm{pH}$ & 6.8 \\
Motion & +++ \\
Motile spermatozoa, \% & 80 \\
$\%$ of sperm with major defects & 5 \\
$\%$ of sperm with minor defects & 5 \\
\hline
\end{tabular}

Two cell lines in blood and also in skin, kidney and spleen were earlier reported in one bull with unilateral cryptorchidism (Miyake et al., 1984).

An analysis of meiotic chromosomes in the testicular biopsies obtained from the bull with karyotype 60,XY/61,XYY, revealed in the most primary spermatocytes 29 autosomal bivalents and a heterosomal bivalent with XY sex chromosomes. Several metaphases were shown to have trivalents with XYY sex chromosomes (Figure 2), what indicates the occurrence of two lines of sex cells. Results

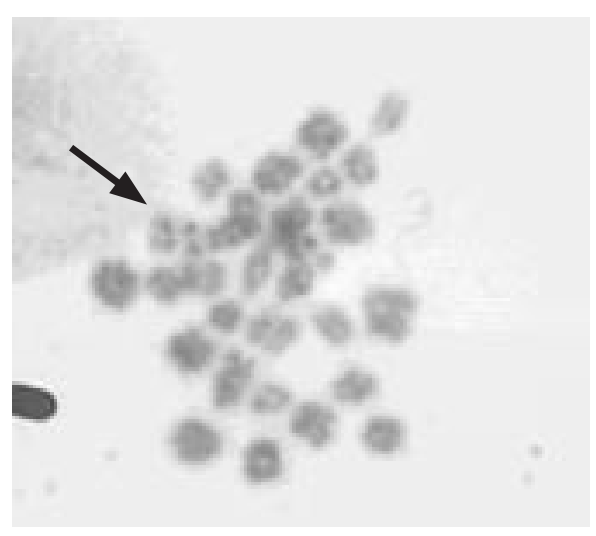

Figure 2. A spermatocyte with a trivalent XYY (arrow) of the semen evaluation are presented in Table 2. When comparing the first ejaculate collection, the quality of the semen obtained from the $60, \mathrm{XY} / 61, \mathrm{XYY}$ bull was similar to that observed for bulls with a normal karyotype. Moreover, the bull examined demonstrated a normal growth and body weight. After slaughter, an examination of the bull's reproductive organs showed their normal development.

It is known that the XYY cell line can arise only through nondisjunction of chromosome $\mathrm{Y}$ during meiosis or mitosis. However, it is not known how two lines with XY and XYY sex chromosomes develop in one individual. The XY/XYY condition could be explained by the implantation of two male zygotes (one XY and one XYY), followed by an exchange of cells between the two zygotes and elimination of the abnormal embryo. This mechanism leads to the appearance of a chimera. The second mechanism is nondisjunction, occurring in a normal zygote during the first embryonic divisions and resulting in a mosaic (Popescu, 1990). In order to determine whether the $60, \mathrm{XY} / 61, \mathrm{XYY}$ bull was a chimera or mosaic, 
JASZCZAK K. ET AL.

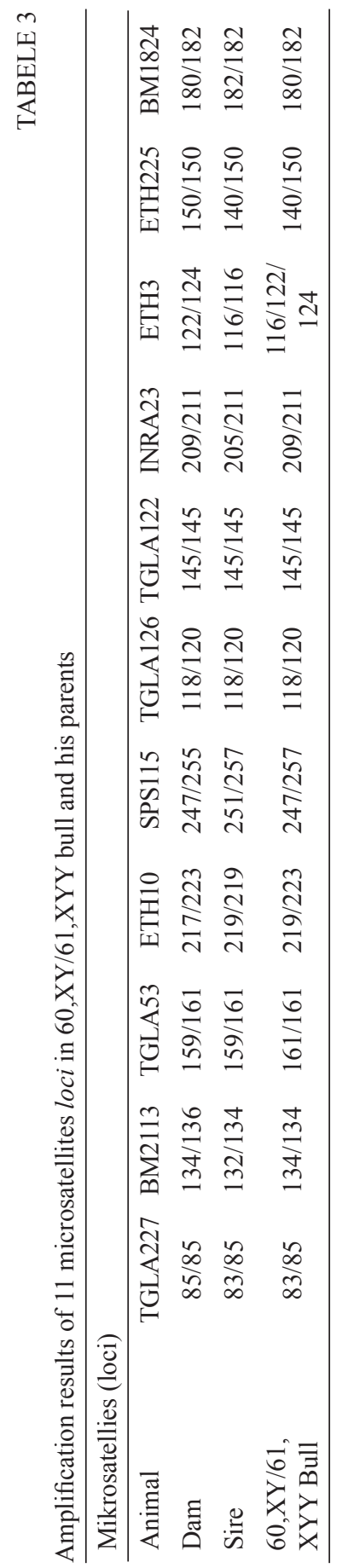


an analysis was carried out of 11 DNA microsatellite loci (Table 3). At three of the loci analysed - TGLA53, TGLA126 and TGLA122, the same alleles were observed in the bull's dam and sire. The identical genotypes at these loci in the parents and their offspring make it impossible to confirm or exclude the occurrence of cell chimerism in the 60,XY/61,XYY bull. The next three loci: TGLA227, ETH225 and BM1824, although not identical in the parents and the bull, show a specific combination of alleles that makes it impossible to exclude the existence of cell chimerism on the basis of the bull's genotype.

In the bull examined three alleles were found at locus ETH3. The identification of two cell lines with genotypes 116/122 and 116/124 bp, indicates the presence of cell chimerism in the bull examined. The same alleles were observed at 11 microsatellite loci, using DNA from two tissues (kidney and spleen) of the 60,XY/61XYY bull.

\section{REFERENCES}

Breeuwsma A.J., 1968. A case of XXY chromosome constitution in an intersex pig. J. Reprod. Fertil. $16,119-120$

Evans B.P., Brekon G., Ford C.E., 1964. An air-drying method for meiotic preparations from mammalian testes. Cytogenetics 3, 289-294

Evans E.P., Beechey C.V., Burtenshaw M.O., 1978. Meiosis and fertility in XYY mice. Cytogenet. Cell Genet. 20, 249-263

Fretz P.B., Hare W.C.D., 1976. A male psudohermaphrodite horse with 63,X)?/64XX/65XXY mixoploidy. Equine Vet. J. 8, 130-132

Gustavsson I., 1984. Chromosome evaluation and fertility. In: $10^{\text {th }}$ International Congress Animal Reproduction, Artificial Insemination. University of Illinois. Ill. 6, 1-7

Höhn H., Klug E., Rieck G.W., 1980. A 63,X0/65,XYY mosaic in a case of questionable equine psudohermaphroditism. In: Proceedings of 4th European Colloquium: Cytogenetic of Domestic Animals. Uppsala, pp. 82-92

Jaszczak K., Parada R., Jaszczak J., 2002. A note a mosaic bull with XY/XYY sex chromosomes. Anim. Sci. Pap. Rep. 20 (3), 187-190

Miyake Y.I., Kanagawa H., Ishikawa T., 1984. Further chromosomal and clinical studies on the XY/XYY mosaic bull. Jpn. J. Vet. Res. 32, 9-21

Popescu P.C., 1990. Chromosome of the cow and bull. In: R.A. McFeely (Editor). Domestic Animal Cytogenetics. Academic Press Inc., pp. 41-71

Skakkebaek N.E., Jacobsen M.P., Mikkelsen M., 1973. Quantification of human seminiferous epithelium. J. Reprod. Fertil. 32, 391-401

Sumner A.T., 1972. A simple technique for demonstrating centromeric heterochromatin. Exp. Cell Res. 75, 304-306 
STRESZCZENIE

Analiza chromosomowa tkanek, jakości nasienia i loci mikrosatelinarnych buhajka z kariotypem 60,XY/61,XYY

W ramach kontroli prawidłowości kariotypu buhajków przeznaczonych do rozrodu stwierdzono przypadek występowania dwóch linii komórkowych z chromosomami 60,XY i 61,XYY w hodowli limfocytów krwi buhajka rasy holsztyńsko-fryzyjskiej. Średni procent komórek z kariotypem 60,XY wynosił 72, a z kariotypem 61,XYY 28. Przeprowadzone dalsze badania cytogenetyczne buhajka w wieku 16 miesięcy wykazały również występowanie dwóch linii komórkowych w hodowli fibroblastów skóry, komórek nerki, śledziony i płuc. Stosunek komórek z kariotypem 60,XY:61,XYY jest następujący: w skórze 72:28, nerce 68:32, śledzionie 62:32 i płucach 61:39. Ponadto badania chromosomów mejotycznych wykazały występowanie biwalentów XY i triwalentów XYY. Buhaj charakteryzował się normalnym wzrostem, masą ciała i dobrze rozwiniętymi narządami płciowymi. Przeprowadzona ocena nasienia buhajka w wieku 14 miesięcy odpowiada przyjętym normom dla reproduktorów w stacjach unasienniania. U buhajka i jego rodziców wykonano analizę polimorfizmu 11 sekwencji mikrosatelitarnych DNA wykorzystując komercyjny zestaw do kontroli pochodzenia StockMarks for Cattle Bovine II v. 2 PCR Typing Kit. Zidentyfikowano dodatkowy trzeci allel w locus ETH3, co wskazuje na występowanie chimeryzmu komórkowego u badanego osobnika. 
